\title{
ACP5 Gene
}

National Cancer Institute

\section{Source}

National Cancer Institute. ACP5 Gene. NCI Thesaurus. Code C99181.

This gene plays a role in glycoprotein dephosphorylation. 